\title{
A qualitative and quantitative analysis of Turkish forest policy documents in the rural development scope
}

\section{Seçil Yurdakul Erol ${ }^{1}$ Hasan Tezcan Yıldırım $^{1^{*}}$}

${ }^{1}$ Istanbul University Faculty of Forestry Department of Forest Policy and Administration, Sarıyer, Istanbul, Turkey. E-mail: htezcan@istanbul.edu.tr. "Corresponding author.

\begin{abstract}
The interaction between forest resources and forest villagers has made rural development a privileged component of Turkish forest policy. In this context the main aim of the study was to investigate the framing of rural development issues in national forest policy by using content analysis method. The economic aspect is the most prominent dimension regarding rural development in the context of national forest policy, environmental and socio-cultural factors follow it respectively. Also, the main approach depends on supporting the forest villagers and its development is seen as an essential tool to protect the forest resources.
\end{abstract}

Key words: forest policy, rural development, content analysis, forest villagers.

A análise qualitativa e quantitativa dos documentos da política florestal Turca no âmbito de desenvolvimento rural

RESUMO: A interação entre os recursos florestais e moradores florestais tornou o desenvolvimento rural em um componente privilegiado da politica florestal turca. Neste contexto, o principal objetivo do estudo é investigar o enquadramento das questões do desenvolvimento rural na política florestal nacional usando o método de análise de conteúdo. Nós descobrimos que o aspecto econômico é a dimensão mais proeminente em relação ao desenvolvimento rural no contexto de política florestal nacional e fatores ambientais e sócio-culturais seguem a mesma respectivamente. Além disso, a principal abordagem para apoiar os moradores florestais e desenvolvimento deles é visto como um instrumento essencial para proteger os recursos florestais.

Palavras-chave: politica florestal, desenvolvimento rural, análise de conteúdo, moradores florestais.

\section{INTRODUCTION}

Forest villagers are those who live in residential areas located either within or nearby forest area in Turkey. They have a critical position in terms of rural development, because forest villages have the lowest levels of income, education, health care, infrastructure, and social opportunities (ATMIŞ et al., 2010; EKIZOĞLU et al., 2010). As a result of this situation, forest villagers have caused some pressure on forest resources. And some problems appear in the utilization of natural resources and land usage (ATMIŞ et al., 2009; GÖL et al., 2011). Thus, forests play an important role in forest villagers' livelihood; and also conservation of forest resources as a natural result interacts with their activities, so they became as one of the most privileged participant of Turkish forestry (TÜRKER et al., 2011; IUCN, 2010; KITAMURA \& CLAPP, 2014; KUVAN, 2012). Preventing the negative effects of forest villagers on forest resources also depends on their capacity to sustain their livelihoods; therefore, it depends on rural development.

The Department of Forest-Village Relations (ORKÖY), which operates under the General Directorate of Forestry, has duties in supporting rural development activities in forest villages. This unit prepares projects regarding social and economic development for these villages, provides credit and grants. The official data indicate 
that the credit granted to forest villages' cooperatives between 1974 and 2010 was approximately $\$ 180$ million. Some individual credits were also funded separate to the cooperatives, on average awarded \$27 million per year (MoFW, 2010). In addition to the financial support, some legal rights were vested to the forest villagers. As a result, they can use industrial and fuel wood for their requirements; they can also sell wood that they buy at reduced prices at markets. Villagers also have rights in terms of the use of non-wood forest products. Moreover, they work for public forest enterprises in harvesting, conserving, maintaining and planting activities. Forests also provide fuelwood, heating cooking, and construction for forest villagers, but forests that have enough potential to supply fuelwood for villagers are under the threat of degradation (TÜRKER et al., 2010). Approximately $500000 \mathrm{~m}^{3}$ of industrial wood and 4.6 million $\mathrm{m}^{3}$ of fuel wood were assigned to forest villagers in the context of legal rights as an annual average between 1990 and 2010. This means that $6.1 \%$ of the total industrial wood production, and $77 \%$ of fuel wood production in Turkey has been utilized by forest villagers for the last 20 years, annually (GDF, 2011).

Despite the support of ORKÖY and legal utilization rights there has not been largescale improvement regarding the living conditions and standards of forest villages. Maintaining rural development in forest villages requires more than legal arrangements and economic support.

Parallel to this situation, the main aim of the study was to express the importance of rural development issues for the forestry sector and also investigate the place and contents of rural development aspects in the context of current Turkish forest policy documents. Further, comparison of the major forest policy documents on rural development issues was another aim reached by using qualitative and quantitative analysis. Also, it was created a hierarchical structure that contained rural development components regarding forestry sector by considering the main axis of global approaches and Turkey case.

\section{MATERIALS AND METHODS}

Forest policy aims are present in related legal arrangements, development plans and some other documents (ERDÖNMEZ et. al., 2010; GÜMÜŞ, 2004). The national forestry documents chosen were the following: The national constitution, current forest law No. 6831, supporting development of forest villages Law No. 2924, 9th development plan (DP) - forestry expert commission report (DPT, 2007) and the Turkish national forestry program (NFP) (MoEF, 2004).

The main components of the concept of rural development in the context of forestry are determined as "rural economy (economic dimension)", "life quality and culture (socio-cultural dimension)" and "protection of rural environment (environmental dimension)".

Elements of the aforementioned components are also categorized in figure 1 . Scientific studies and some national documents were used as the essential resources for concepts determination (BACON et al., 2012; BOWE \& MARCOUILLER, 2007; ERDÖNMEZ \& ÖZDEN，2009; ERDÖNMEZ \& YURDAKUL EROL, 2010; GALDEANO-GÓMEZ et al., 2016; MADU, 2007; MoARA, 2010). To standardize the process, 10 expressions were determined for each category. The presence of expressions listed in figure 1 was researched in the cited national documents. An assessment was then made to determine the amount and frequency of these expressions in the documents.

Content analysis was used as the main research method in this study. Prasad (2008) defined content analysis as a research technique for making replicable and valid inferences from data to their context. Thus, content analysis is all about making valid, replicable and objective inferences about the message on the basis of explicit rules. Furthermore, STEMLER (2001) wrote that when used properly, content analysis is a powerful data reduction technique and also its major benefit comes from the fact that it is a systematic, replicable technique for compressing many words of text into fewer content categories based on explicit rules of coding. The main purposes of this method are; i) to acquire systematic data about texts and analyze them; ii) to determine and reveal the hidden meanings and deduce the different dimensions (BILGIN, 2006; GÖKÇE, 2006).

The steps followed in this study are listed below:

a. Formulation of the research question and objectives: i) "examination of the contents and approaches of Turkish forest policy in terms of rural development" ii) to create a hierarchical structure of rural development components in forestry, and iii) to compare major forest policy documents on rural development issues.

b. Selection of sample: The main current national forest policy documents (National Constitution, Forest Law No. 6831, Supporting Development of 


\begin{tabular}{|c|c|c|}
\hline & RURAL DEUELOPMENT IN FORESTRY & \\
\hline $\begin{array}{c}\text { Rural Economy } \\
\text { (Economic Dimension) }\end{array}$ & $\begin{array}{l}\text { Life Quality and Culture } \\
\text { (Socio-Cultural Dimension) }\end{array}$ & $\begin{array}{c}\text { Rural Environment } \\
\text { (Exvironmental Dimension) }\end{array}$ \\
\hline $\begin{array}{l}\text {-Credit-Support-Investment } \\
\text {-Employment- Employmert } \\
\text { in Forestry } \\
\text {-Agiculture- Livestock } \\
\text {-Orgarizing-Cooperatives } \\
\text {-Industry-Forest Industry } \\
\text {-Tourism-Rural Tourigm } \\
\text {-Fishery } \\
\text {-Apiculture } \\
\text {-Handicrafts- Local Products } \\
\text {-Legal Forest Utilization } \\
\text { Rights } \\
\text {-Industrial Wood } \\
\text {-Fuel wood } \\
\text {-Non-Wood Forest Products } \\
\text {-Grasing }\end{array}$ & $\begin{array}{l}\text {-Transportation } \\
\text {-Education } \\
\text {-Health care } \\
\text {-Migration } \\
\text {-Infrastructure } \\
\text {-Housing-Rural Settlement } \\
\text {-Foverty } \\
\text {-Food Security } \\
\text {-Ownership } \\
\text {-Culture } \\
\text {-Tongible Culture: buildings- } \\
\text { equipment-dresses-forestry } \\
\text { methods etc. } \\
\text {-Intangible Culture: } \\
\text { belieff, traditions, nom } \\
\text { traditional lowowledge etc. }\end{array}$ & $\begin{array}{l}\text {-Clean Water Utilization } \\
\text { and Protection } \\
\text {-Preventing Pollution } \\
\text {-Renewable Energ- } \\
\text { Bioenergy } \\
\text {-Soil Protection } \\
\text {-Afforestation and } \\
\quad \text { Reforestation } \\
\text {-Forest Fires Fighting } \\
\text {-Land misuses } \\
\text { - Waste Manggement } \\
\text {-Protected Areas } \\
\text {-Biodiversity }\end{array}$ \\
\hline
\end{tabular}

Forest Villages Law No. 2924, 9th Development Plan - Forestry Expert Commission Report and National Forestry Program).

c. Forming content categories: "rural economy", "life quality and culture" and "protection of rural environment" (Figure 1).

d. Determining units and counting method of analysis: d.1. The recording unit of the analysis was determined as "words and terms.", The context units were the sentences.

d.2. The counting of the units was performed by frequencies.

e. Analyzing the collected data: The related results of the analysis are explained in "Findings".

Also, the scopes of the related articles, policies, strategies, principles etc. were examined in terms of their meanings and relations. Thus, a more analytical approach was used to show the content of the Turkish forest policy on rural development. Moreover, the coverage of the categories and units (expressions) in the whole document was analyzed, and, the frequency of these components and the amounts of documents refer to them was determined.

\section{RESULTS}

The findings are divided in four parts: economic, socio-cultural, environmental dimensions, and a comprehensive evaluation.

Economic Dimension of Rural Development Issues in Forest Policy Documents

The total number of expressions that were determined as components of the rural economy was 154 in all five documents and these documents referred rural economy aspects in 89 out of 427 
pages. Approximately half of these expressions (80) were reported in DP and words regarding economic dimension appeared in 38 pages, but when the percentage of coverage was considered it was found mostly in Law on Supporting Forest Villages with a value of $60 \%$ (Table 1 ). The most common words reported in the related texts on economic dimension of rural development were ranked as "creditsupport-investment", "organization-cooperatives", "agriculture-livestock", “employment-employment in forestry" and "legal forest utilization rights".

Government has authorities in terms of maintaining land for the people who are engaged in farming according to the Turkish National Constitution. Also, government supports the people who are engaged in agriculture and livestock. Also, $170^{\text {th }}$ article of the national constitution stated that legal arrangements are related to the areas that scientifically lose their forest property and they are improved and designed properly for settlement of forest villagers to maintain their development.

Furthermore, the forest law has articles related to supporting development of forest villagers by using some funds and gives some rights and priority to forest villagers and their cooperatives in terms of working in harvesting activities and utilizing harvested wood material, so these activities have become a part of their livelihood and rural socioeconomic structure. Also, they have some utilization rights regarding having some industrial wood and fuelwood for their individual or collective needs. Moreover, they have sale right in the market of wood material that they bought by paying reduced prices, determined for them. Besides, the main axis of the law on supporting development of forest villages is settlement of the forest villagers who are decided to be transferred and usage of the areas that are decided to be taken out of forest borders in the context of development of forest villagers. Also, as required by this law government gives credits to forest villagers. The main approaches of DP are related to legal recovery and increment of credits in accordance with increment of employment opportunities and participatory mechanisms. Further, forest and public relations is described as one of the main activities as a sectoral development axis, and supporting forest villagers is revealed as an important component of national development. In the context of NFP, the themes are examined related to financial structure of forestry, development of relations with forests and villages, support for development of forest villages, utilization of forest resources, contribution to reduction of poverty, improvement of living conditions of forest villagers. This policy document expresses the necessity of classification and ranking of the forest villages in terms of their economic, social and cultural properties, poverty levels, dependency on forest, development potential to determine the supporting priorities. The other important approaches of the document in terms of alleviating poverty and increasing the living conditions of local people are promoting new funding mechanisms and collaboration opportunities, planning and application of integrated rural development models with other sector.

\section{Socio-Cultural Dimension of Rural Development} Issues in Forest Policy Documents

There were a total of 49 expressions counted regarding socio-cultural dimensions of rural development in the all five documents and also all of them were in 34 out of 427 pages. When the distribution of these expressions among the related documents was examined it was seen that NFP had 26 and they were encountered in 17 pages (\%18.89). When the page coverage percentages were considered it was understood that law on supporting forest villages' coverage percentage $(\% 40)$ was greater than the others (Table 1). The National Constitution, Forest Law, and Law on Supporting Development of Forest Villages expressed socio-cultural issues only once or twice and the socio-cultural dimension of rural development was mostly represented by the expressions of "migration", "education", "poverty" and "ownership" (Table 1).

The Turkish national constitution has an article related to the right of the people on living in a healthy environment and the responsibility of the government about maintaining sustainable conditions in terms of physical and mental health. Also, according to the forest law, forestry organization supports for the public common needs. The other related legal arrangement, law on supporting development of Forest Villages, contains some principles related to the ownership of the lands that lost their forest property and utilizing these lands to support the development of forest villages. Also, DP expresses the importance of education of rural people to support the capacity building of forest villagers. The plan highlights the effects of migration, participation of rural people to natural resources management, maintaining occupational safety and equitable utilization from the resources, strengthening collaboration with other public institutions and non-governmental organizations. NFP defines education in relation to both capacity building and nature protection. In addition, low income levels, poverty and insufficient 
Table 1 - Frequencies of the expressions related dimensions of rural development. For CR tables, please no more than three solid lines. The rest must be deleted or replaced with dotted lines

\begin{tabular}{|c|c|c|c|c|c|}
\hline $\begin{array}{c}\text { National } \\
\text { constitution }\end{array}$ & Forest law & $\begin{array}{c}\text { Law on } \\
\text { supporting } \\
\text { development } \\
\text { of forest } \\
\text { villages }\end{array}$ & $\begin{array}{c}9^{\text {th }} \\
\text { Development } \\
\text { plan forestry } \\
\text { expert } \\
\text { commission }\end{array}$ & $\begin{array}{l}\text { National } \\
\text { forestry } \\
\text { program }\end{array}$ & TOTAL \\
\hline
\end{tabular}

\begin{tabular}{|c|c|c|c|c|c|c|c|c|c|c|c|c|}
\hline \multirow{3}{*}{ Total Pages } & \multicolumn{2}{|c|}{182} & \multicolumn{2}{|c|}{38} & \multicolumn{2}{|c|}{5} & \multicolumn{2}{|c|}{112} & \multicolumn{2}{|c|}{90} & \multicolumn{2}{|c|}{427} \\
\hline & \multicolumn{12}{|c|}{------------------------------------------------------------Frequencies----------------------------------------------------------- } \\
\hline & $\mathrm{A}^{*}$ & $\mathrm{~B}^{* *}$ & $\mathrm{~A}^{*}$ & $\mathrm{~B}^{* *}$ & $\mathrm{~A}^{*}$ & $\mathrm{~B}^{* *}$ & $\mathrm{~A}^{*}$ & $\mathrm{~B}^{* *}$ & $\mathrm{~A}^{*}$ & $\mathrm{~B}^{* *}$ & $\mathrm{~A}^{*}$ & $\mathrm{~B}^{* *}$ \\
\hline \multicolumn{13}{|c|}{ - } \\
\hline $\begin{array}{l}\text { Credit-support- } \\
\text { investment }\end{array}$ & & & & & 2 & 2 & 38 & 13 & 14 & 8 & 54 & 23 \\
\hline $\begin{array}{l}\text { Employment- } \\
\text { employment in forestry }\end{array}$ & & & 1 & 1 & & & 9 & 6 & 4 & 3 & 14 & 10 \\
\hline Agriculture-livestock & 6 & 2 & 4 & 1 & 2 & 1 & 6 & 5 & 3 & 2 & 20 & 11 \\
\hline $\begin{array}{l}\text { Organization } \\
\text { cooperatives }\end{array}$ & & & 12 & 5 & & & 21 & 9 & 9 & 8 & 42 & 22 \\
\hline Industry- forest industry & & & & & & & & & 1 & 1 & 1 & 1 \\
\hline Tourism-rural tourism & & & & & & & 3 & 2 & 4 & 4 & 7 & 6 \\
\hline Fishery & & & & & & & & & 3 & 3 & 3 & 3 \\
\hline Apiculture & & & & & & & & & 1 & 1 & 1 & 1 \\
\hline \multicolumn{13}{|l|}{$\begin{array}{l}\text { Handcrafts-local } \\
\text { products }\end{array}$} \\
\hline $\begin{array}{l}\text { Legal forest utilization } \\
\text { rights }\end{array}$ & 1 & 1 & 2 & 2 & & & 3 & 3 & 7 & 6 & 13 & 12 \\
\hline Total frequency & 7 & 3 & 19 & 9 & 3 & 3 & 80 & 38 & 46 & 36 & 154 & 89 \\
\hline Total Percentage $(\%)$ & 4.52 & 1.65 & 12.26 & 23.68 & 1.94 & 60.00 & 51.61 & 33.93 & 29.68 & 40.00 & 100.00 & $20.84^{* * *}$ \\
\hline \multicolumn{13}{|c|}{ 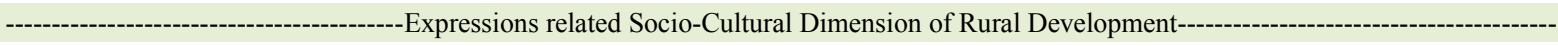 } \\
\hline Transportation & & & 1 & 1 & & & 1 & 1 & 1 & 1 & 3 & 3 \\
\hline Education & & & & & & & 7 & 2 & 5 & 4 & 12 & 6 \\
\hline Health care & 1 & 1 & 1 & 1 & & & & & & & 2 & 2 \\
\hline Migration & & & & & & & 2 & 1 & 11 & 5 & 13 & 6 \\
\hline Infrastructure & & & 1 & 1 & & & & & & & 1 & 1 \\
\hline Housing-rural settlement & & & & & & & 1 & 1 & & & 1 & 1 \\
\hline Poverty & & & & & & & 2 & 2 & 5 & 3 & 7 & 5 \\
\hline Food Security & & & & & & & & & 2 & 2 & 2 & 2 \\
\hline Ownership & & & & & 2 & 2 & 3 & 3 & & & 5 & 5 \\
\hline Culture & & & & & & & 1 & 1 & 2 & 2 & 3 & 3 \\
\hline Total frequency & 1 & 1 & 3 & 3 & 2 & 2 & 17 & 11 & 26 & 17 & 49 & 34 \\
\hline Total Percentage $(\%)$ & 2.04 & 0.55 & 6.12 & 7.89 & 4.08 & 40.00 & 34.69 & 9.82 & 53.06 & 18.89 & 100.00 & $7.96^{* * *}$ \\
\hline \multicolumn{13}{|c|}{ - } \\
\hline $\begin{array}{l}\text { Clean water utilization } \\
\text { and protection }\end{array}$ & & & 2 & 2 & & & & & & & 2 & 2 \\
\hline Preventing pollution & 1 & 1 & & & & & & & & & 1 & 1 \\
\hline $\begin{array}{l}\text { Renewable-energy- } \\
\text { bioenergy }\end{array}$ & & & & & & & 1 & 1 & & & 1 & 1 \\
\hline Soil protection & & & & & & & 1 & 1 & & & 1 & 1 \\
\hline $\begin{array}{l}\text { Afforestation and } \\
\text { reforestation }\end{array}$ & & & 4 & 3 & & & 19 & 9 & 16 & 7 & 39 & 19 \\
\hline Forest fires fighting & & & 8 & 4 & & & 2 & 2 & 1 & 1 & 11 & 7 \\
\hline Protected areas & & & & & & & 4 & 4 & 2 & 2 & 6 & 6 \\
\hline Land misuses & & & & & & & 1 & 1 & & & 1 & 1 \\
\hline Waste management & & & 1 & 1 & & & & & & & 1 & 1 \\
\hline Biodiversity & & & & & & & 1 & 1 & 1 & 1 & 2 & 2 \\
\hline Total frequency & 1 & 1 & 15 & 10 & 0 & 0 & 29 & 19 & 20 & 11 & 65 & 41 \\
\hline Total Percentage (\%) & 1.53 & 0.55 & 23.08 & 26.32 & 0.00 & 0.00 & 44.62 & 16.96 & 30.77 & 12.22 & 100,00 & $9.60^{* * *}$ \\
\hline
\end{tabular}

${ }^{*}$ A Frequency (in the document); ${ }^{* *}$ B Page coverage; ${ }^{* * *}$ Coverage percentages in all documents. 
infrastructure opportunities and social services are indicated as main reasons for migration that changes socio-cultural structure of rural areas.

\section{Environmental Dimension of Rural Development Issues in Forest Policy Documents}

The total number of expressions regarding environmental dimension of rural development in the sample of forest policy documents was 65 and covered in 41 pages. DP had $44.6 \%$ of these expressions and also the amount of coverage was 19 pages (\%16.96). When the page coverage percentages were considered it was seen that forest law's coverage was 10 out of 38 pages $(\% 26.32)$ which had the highest coverage percent among the documents (Table 1). Environmental dimension was represented mostly by the expressions of "afforestation-reforestation", "fighting forest fires" and "protected areas".

It is mentioned in the National Constitution that all the citizenships have the right to live in a healthy and balanced environment. Parallel to this main principle, Forest Law doesn't take any charge for the rights that are given for clean water and related infrastructures. Besides, to support the environmental dimension in rural areas, there is an article of this law regarding afforestation activities that can be made by forest village entity to with the permission of forest organization or the appropriate areas can be afforested by forestry organization if the village entity has a demand. The same law contains a legal obligation regarding forest villagers on going to fire place and fighting forest fires.

In DP, it is mentioned that the main reason for biotic and abiotic damages of forests depends on rural poverty. Thus, the environmental issues are examined together with economic and educational issues. Further, supporting utilization of environmentally friendly energy resources in rural areas is seen as a tool for environment protection. Lots of forestry activities like afforestation, erosion control, green belt plantations, supporting private and industrial plantations, planting trees in some agricultural lands etc. are seen as tools for enlarging forest areas maintaining nature protection and sustainability in rural development. NFP touches upon supporting forestation activities that are made by forest villagers in degraded forest areas, other non-forested areas and their own lands, also in agroforestry applications and plantations with fast-growing species is another approach of this document in terms of maintaining forest resources protection. Moreover, collaboration of rural people in combating against desertification, protection of soil and water resources, wildlife management, sustaining biodiversity, preventing forest fires, determination, planning, conservation and control of protected areas is seen as important components for development and protection of forests.

\section{A comparative evaluation}

As a finding of this research, "Creditsupport-investments" is the most common expression in Turkish forestry based policy documents. "Organizations \& cooperatives", "afforestation \& reforestation", "agriculture \& livestock" are also the important elements that cited respectively. These expressions are followed by "employment", "legal utilization rights", "migration", "education" and "fighting forest fires". Parallel to the Turkish experience, HYTTINEN et al. (2000) discussed the key role of encouragement of entrepreneurial activities in terms of rural development. SIKORA \& NYBAKK (2012) expressed the importance of institutional support for rural development. SEELAND et al. (2011) and ESPARCIA (2014) described the place of innovation and modernization for effective rural development.

Furthermore, another important finding from our research was that the content of legal arrangements is less comprehensive than national plans and programs. While $18.4 \%$ of the total assessed expressions were reported in law-based documents. Therefore, it could be argued that the legal background of forestry-oriented rural development issues should be strengthened and enriched. Also, "strengthening legal base" issue is expressed in Rural Development Plan (2010-2013) under many strategy titles (MoARA, 2010).

Supporting development of forest villages is accepted as one of the main Turkish forest policy aims in national policy tools as legal and nationwide plans levels. Furthermore, the main approach of the conventional forest policy on rural development depends on supporting the villagers, but the local people haven't been properly accepted as one of the participants in decision making process, and the participatory mechanisms aren't sufficiently promoted.

Generally, all of the documents have parallel approaches. Definitely, there are some differences about the tools to maintain development, but the main axis is similar. We reported that the economic aspect is the most prominent dimension regarding rural development in the context of forest policy. If the sample documents are assessed, it is clear that the economic issues are the mostly highlighted dimension in each of them. The total percentage of economy-based expressions is $57.4 \%$, followed by environmental (24.3\%) and socio-cultural 
$(18.3 \%)$ issues, respectively. It is possible to find this result in both qualitative and quantitative analysis. The frequency of the total of environmental factors is less than half of economic factors' frequency, whereas the socio-cultural factors' frequency is relatively less than $1 / 3$ of the economic factors' frequency. Parallel to this finding, the main factors of forest villagers' development in current documents have been still focused on credits, employment opportunities, and legal rights in terms of discounted sales. They also still define the combat against migration as a tool for decreasing the socioeconomic pressures on forests and the rural development as a tool for protecting the forests.

\section{DISCUSSION AND CONCLUSION}

Results of the content analysis for current forest policy documents showed that the economic dimension is more prominent than the other dimensions in the Turkish experience. RÂMNICEANU \& ACKRILL (2007) also reported that economic factors have an impact on policy takeup in terms of rural development. Undoubtedly, economy is one of the key factors in the rural development process, but it should be considered that it is impossible to ensure sustainable development in forestry without environmental and socio-cultural dimension. Parallel to this perspective, the necessity of an ecosystem-based approach, consideration of social values, multifunctional and sustainable land use, and development of human capacity has to be prioritized rather than rural richness. ELANDS et al. (2004) supported this approach and expressed those forests are the foremost valued ones in relation to their perceived contribution to the rural identity rather than in relation to their rural production and income generation capacity. Also, the EU founded project of (Winging and coaching the civil society of Alibunar to approach the EU rural development") LEADER+ (2011), expressed that "To enhance competitiveness, investment support for physical capital will remain important. At the same time, investments in human and social capital will be even more important to enable agriculture and forestry to remain an innovative and dynamic sector contributing to growth in rural areas". In this regard, by a holistic view, the components of rural development should be focused on social, demographic, human-cultural, infrastructural and especially environmental variables in the context of forestry perspective (YILMAZ et al., 2010).

Furthermore, the other important conclusion of the research is about content of legal documents. The content of them is less comprehensive than the other policy documents. Thus, as an important policy instrument, the content of the legal documents should be broad in terms of diversity of development tools. In addition, the main findings showed that participation of rural people in policy making process is not common. Undoubtedly, effective participatory mechanisms can increase the effectiveness of the content of policy documents.

In the current national forest policy documents, the prominent solutions regarding maintaining rural development in forest villagers can be summarized as: i) national level, multi-sectoral policies and integrated models are needed, ii) institutional, legal, human resources and financial arrangements have to be strengthened, iii) collaboration and cooperation have to be formed between related institutions and the activities should be coordinated by forestry institution, iv) the capacity of forest villagers should be developed in terms of problem solving, assertion, raising awareness, strengthening the organization culture and structure of forest villagers to make them an active and productive society, v) developing the functional and participatory management capacities and maintaining equal sharing.

Consequently, EKIZOĞLU et al. (2010) made an evaluation for rural development approach of Turkey "Rural development has never been a prominent issue among policy aims in the country. Instead, rural development is seen as a little coach that drifts at the end of the development train. Unfortunately, it is not perceived that rural development could be a locomotive for this train". Therefore, the policies have to be strengthened, the decisions have to be implemented and a control mechanism that depends on criteria and indicators has to be formed. Thus, it is possible for Turkish forestry to maintain a sustainable rural development that will lead countrywide development.

Results of the study are important in terms of guiding the further policy making processes. It is seen that there are some different approaches in various policy documents, but the main axis of them is similar. Diversity of development mechanisms and considering these mechanisms according to the regional and local properties could support the success of implementation process. In addition, the results contribute local land managers in terms of considering the development aspect in a border frame rather than economic dimension such as credits ad employment opportunities.

There are some limitations in terms of method used in the research. Content analysis is a descriptive method; thus, the research is limited by the 
expressions of the texts. The analyzed policy documents may not reflect the details and implementation fundamentals. Thus, the relationship between the policy documents and implementation results should also be analyzed through additional research. It may; therefore, be possible to analyze the reflect of the decisions to rural development in forest regions.

\section{ACKNOWLEDGMENTS}

This study was supported by the Research Fund of the University of Istanbul. Project Number: UDP-23483.

\section{REFERENCES}

ATMIȘ, E. et al. Factors affecting forest cooperative's participation in forestry in Turkey. Forest Policy and Economics, v.11, p.102-208, 2009. Available from: $<\mathrm{http} / / \mathrm{dx}$.doi.org/10.1016/j.forpol.2008.10.002>. Accessed: Oct. 15, 2015. doi:10.1016/j.forpol.2008.10.002.

ATMIŞ, E. et al. How can Turkey's forest cooperatives contribute to reducing rural poverty? Unasylva, v.61, n.234/235, p.51-53, 2010. Available from: <http://www.fao.org/docrep/012/i1507e/ i1507e10.pdf $>$. Accessed: Oct. 15, 2015.

BACON, C.M. et al. The social dimensions of sustainability and change in diversified farming systems. Ecology and Society, v.17, n.4, p.41, 2012. Available from: <http://www.ecologyandsociety.org/vol17/iss4/ art41/>. Accessed: Dec. 10, 2015. doi: org/10.5751/ES-05226-170441.

BILGIN, N. Sosyal bilimlerde içerik analizi: teknikler ve örnek çalişimalar (content analysis in social sciences: techniques and cases). Siyasal Kitabevi, Ankara:, 2006. Total de p.230.

BOWE, S.A.; MARCOUILLER, D.W. Alternative tourism-timber dependencies and the development of forested rural regions. Forest Policy and Economics, v.9, n.6 p.653-670,2007. Available from: $<$ http:// www.sciencedirect.com/science/article/pii/S1389934106000608>. Accessed Nov. 8, 2015.

DPT (STATE PLANNING ORGANIZATION). 9. Beş yillik kalkinma plani ormancilik özel ihtisas komisyonu (Special Report on Forestry of 9th Five Year Development Plan), Devlet Planlama Teşkilatı, Ankara, Turkey, 2007. Total de p. 102.

EKIZOĞLU, A. et al. Ormancilikla ilgili diğer politikalar (Other policies relevant to forestry) (in Turkish). Ormancilik Politikası (Forest Policy) (in Turkish) (Ed. Akesen, A., Ekizoğlu, A.). Ankara: Özdoğan Matbaa Yayın Ltd. Şti., 2010. (Türkiye Ormancılar Derneği Eğitim Dizisi Yayın No: 6).

ELANDS, B.H.M. et al. Forests as a mirror of rural conditions; local views on the role of forests across Europe. Forest Policy and Economics, v.6, p.469-482, 2004. Available from: <http:// www.sciencedirect.com/science/article/pii/S1389934104000176>. Accessed: Apr. 21, 2015. doi: org/10.1016/j.forpol.2004.01.003.

ERDÖNMEZ, C.; ÖZDEN, S. Relations between rural development projects and urban migration: the Köykent Project in Turkey. Ciência Rural, v.39, n.6, p.1873-1879, 2009. Available from: $<$ http://www.scielo.br/scielo.php?script=sci_arttext\&pid=S010384782009000600037\&lng=en\&nrm=iso\&tlng=en $>$. Accessed: Apr. 16, 2015. doi: .org/10.1590/S0103-84782009005000091.
ERDÖNMEZ, C. et al. Türkiye'de ormancilik politikası (Turkish forest policy (in Turkish)). Ormancilık Politikası (Forest Policy) (in Turkish) (Ed. Akesen, A., Ekizoğlu, A.). Ankara: Özdoğan Matbaa Yayın Ltd. Şti., 2010. (Türkiye Ormancılar Derneği Eğitim Dizisi Yayın, No: 6).

ERDÖNMEZ, C.; YURDAKUL EROL, S. Historical development of forest-community relations in Poloneköy (Adampol). Sylwan, v.154, n.5, p.291-298, 2010. (Not available online).

ESPARCIA, J. Innovation and networks in rural areas. An analysis from European innovative projects. Journal of Rural Studies, v.34, p.1-14, 2014. Available from: <http://www.sciencedirect.com/ science/article/pii/S0743016713000995>. Accessed: Apr. 16, 2015. doi:org/10.1016/j.jrurstud.2013.12.004.

GALDEANO-GÓMEZ, E. et al. The social dimensions as a driver of sustainable development: the case study farms in southeast Spain. Sustainability Science, v.11, n, 2 p.349-362. Available from: <http:// link.springer.com/article/10.1007/s11625-015-0318-4>. Accessed: Jan. 18, 2015. doi: 10.1007/s11625-015-0318-4, 2016.

GDF (GENERAL DIRECTORATE OF FORESTRY). Unpublished Statistical Data of General Directorate of Forestry, 2011.

GÖKÇE, O. İçerik Analizi: Kuramsal ve Pratik Bilgiler (Content Analysis: Theory and Practical Knowledge) (in Turkey). Siyasal Kitabevi, Ankara: 2006. Total de p. 122.

GÖL, C. et al. Interactions between rural migration and land use change in the forest villages in the Gökçay Watershed. Turkish Journal of Agriculture and Forestry, v.35, p.247-257, 2011. Available from: $<$ http://dergipark.gov.tr/download/article-file/119595>. $\quad$ Accessed: May. 17, 2015. doi:10.3906/tar-0912-583.

GÜMÜȘ, C. Ormancılık politikası (Forest policy) (in Turkish). Trabzon, Turkey: Karadeniz Teknik Üniversitesi Matbaası, 2004. (Karadeniz Teknik Üniversitesi Orman Fakültesi, Genel Yanın No: 216, Fakülte Yayın No: 34).

HYTTINEN, P. et al. New challenges for the forest sector to contribute to rural development in Europe. Land Use Policy, v.17, p.221-232, 2000. Available from: <http://www.sciencedirect.com/ science/article/pii/S0264837700000144>. Accessed: May. 21, 2015. doi: org/10.1016/S0264-8377(00)00014-4.

IUCN. Bio-cultural diversity conserved by indigenous peoples and local communities-examples and analysis. Available from: $<\mathrm{http}: / /$ pubs.iied.org/pdfs/G02786.pdf. Companion Document to IUCN/ CEESP Briefing, 2010>. (Note No: 10). Accessed: May. 21, 2015.

KITAMURA, K.; CLAPP, R.A. Common property protected ares: community control in forest conservation. Land Use Policy, v.34, p.204-212, 2013. Available from: <http://www.sciencedirect.com/ science/article/pii/S0264837713000549>. Accessed: May. 21, 2015. doi: org/10.1016/j.landusepol.2013.03.008.

KUVAN, Y. Doğa koruma ve korunan alanlar (nature conservation and protected areas). Istanbul: İstanbul University İstanbul, 2012. (Publication No: 5066, ISBN: 978-975-404-914-5).

LEADER + . Winging and coaching the civil society of Alibunar to approach the EU rural development. Delegation of the European Union to the Republic of Serbia Under the EU funded 'Strengthening Serbia-EU Civil Society Dialogue' Project, 2011. Available from: $<$ http://leader.org.rs/csd/files/Information_pack2.pdf $>$. Accessed: Nov. 21, 2015. 
MADU, I.A. Spatial Patterns and the Underlying Factors of Rural Development in the Nsukka Region of Southeastern Nigeria. Journal of Rural and Community Development, v.2, n.2, p.110-122, 2007. Available from: <https://www.researchgate.net/ profile/Ignatius_Madu2/publication/228465547_The_underlying factors_of_rural_development_patterns_in_the_Nsukka_Region of_Southeastern_Nigeria/links/02e7e5247c $\overline{7}$ e9c04e8000000.pdf $>$. Accessed: Feb. 19, 2015.

MoARA (MINISTRY OF AGRICULTURE AND RURAL AFFAIRS). Kırsal Kalkınma Planı (2010-2013) (Rural Development Plan (2010-2013)) (in Turkish). Ankara: Tarım ve Köy İşleri Bakanlığı, 2010. Available from: <http://kkp.tarim.gov.tr/sp/Kirsal Kalkinma Plani\%20(2010-2013).pdf >. Accessed. Nov. 21, 2015. Total de p. 252.

MoEF (MINISTRY OF ENVIRONMENT AND FORESTRY). Türkiye Ulusal Ormancılık Programı (Turkish National Forestry Program). Ankara, Turkey: Çevre ve Orman Bakanlığı Yayınları, 2004. Available from: <https://www.ogm.gov.tr/ekutuphane/Dokumanlar/ Ulusal_Ormancilik_Programi_2004_2023.pdf>. Accessed: Feb., 19, 2015. Total de p. 90 .

MoFW (MINISTRY OF FORESTRY AND WATER AFFAIRS). Forestry Statistics 2010. Ankara, Turkey: Turkish Statistical Institute, Printing Division, 2010. Total de p.5.

PRASAD, B.D. Content analysis: a method in social science research. In: BHASKARAN Lal Das, D.K. (Ed.). Research methods for social work. New Delhi: Rawat Publications, 2008. p.173-193.

RÂMNICEANU, I.; ACKRILL, R. EU rural development policy in the new member states: promoting multifunctionality? Journal of Rural Studies, v.23, p.416-429, 2007. Available from: <http:// www.sciencedirect.com/science/article/pii/S0743016706000702>. Accessed: Jun. 12, 2015. doi: org/10.1016/j.jrurstud.2006.10.003.
SEELAND, K. et al. Regional forest organizations and their innovation impact on forestry and regional development in central Switzerland. Forest Policy and Economics, v.13, p.353-360, 2011. Available from: <http://www.sciencedirect.com/science/article/pii/ S1389934111000293>. Accessed: Jun. 12, 2015. doi: .org/10.1016/j. forpol.2011.03.010.

SIKORA, A.T.; NYBAKK, E. Rural development and forest owner innovativeness in a country in transition: Qualitative and quantitative insights from tourism in Poland. Forest Policy and Economics, v.15, p.3-11, 2012. Available from: <http://www.sciencedirect.com/ science/article/pii/S1389934111001584>. Accessed: Jun. 12, 2015. doi: org/10.1016/j.forpol.2011.09.003.

STEMLER, S. An overview of content analysis. Practical Assessment, Research \& Evaluation, v.7, n.17, p.1-6, 2001. Available from: $<$ http://PAREonline.net/getvn.asp?v=7\&n=17>. Accessed: Dec. 02, 2015.

TÜRKER, M.F. Forest biomass as a source of renewable energy in Turkey. Energy Sources, v.21, n.8, p.705-714, 2010. Available from: <http://www.tandfonline.com/doi/ abs/10.1080/00908319950014443>. Accessed: Dec. 2, 2015. doi: org/10.1080/00908319950014443.

TÜRKER, M.F. et al. Socio-economic, cultural and demographic structures of Turkish forest villages and development approaches, 2011. Available from: <http://fao.org/DOCREP/ARTICLE/WFC/ XII/0412-A2.HTM>. Accessed: July 14, 2015.

YILMAZ, B. et al. Factors affecting rural development in Turkey: Bartın case study. Forest Policy and Economics, v.12, p.239-249, 2010. Available from: <http://www.sciencedirect.com/science/article/ pii/S1389934110000183>. Accessed: Dec. 2, 2015. doi: org/10.1016/j. forpol.2010.02.003. 